\title{
THE COASTAL CURRENT SOUTH OF JAVA
}

by

RD. E. SOERIAATMADJA

This paper concerns investigations of the hydrography of the waters south of Java, especially of the Java Coastal Current, which have been carried out by the Institute of Marine Research at Djakarta.

It is based on (1) oceanographic observations made by the research vessel "SAMUDERA" in February 1957, (2) the surface salinity data of the years 1949-1955, consisting of about 700 observations which were collected by the Institute of Marine Research at Djakarta, and (3) the surface current data obtained from the Atlas of Oceanographic and Meteorological data of the Koninklijk Nederlands Meteorologisch Instituut.

The area surveyed, includes the region between $7^{\circ}$ and $8^{\circ} \mathrm{S}$., extending from $105^{\circ}$ to $110^{\circ} \mathrm{E}$.; and the region between $8^{\circ}$ and $9^{\circ} \mathrm{S}$., extending from $109^{\circ}$ to $114^{\circ} \mathrm{E}$., occupying the western part and the eastern part of the coastal waters south of Java, respectively. The two sections from where the SAMUDERA has obtained oceanographic observations are situated south of Java, crossing the Java Coastal Current in about $108^{\circ} \mathrm{E}$. and $113^{\circ} \mathrm{E}$., respectively. (Fig. 1).

The annual variation of the directions and the velocities of the current south of Java are given in Fig. 2. In the region between Java and Australia, the South Equatorial Current is formed under the influence of the trade winds of the Indian Ocean. This current is a broad wind-drift, which sets during the whole year between $10^{\circ}$ and $20^{\circ} \mathrm{S}$. to the west.

During the months from July to October, this westgoing current extends to the north beyond $10^{\circ} \mathrm{S}$. and reaches the south coast of Java. At the same time, the southeast monsoon is developing, the season wherein a strong wind blows from east to west and reinforces the South Equatorial Current along the south coast of Java. The reinforced current is noted to be stronger in the western part than that in the eastern part. The greatest velocities of $14 \mathrm{~cm} / \mathrm{sec}$ in the eastern part and $23 \mathrm{~cm} / \mathrm{sec}$ in the western part are found during this period.

At the end of the southeast monsoon in about November, the South Equatorial Current gradually shifts southward and along the south coast, the Java Coastal Current is formed which is directed from west to east. 


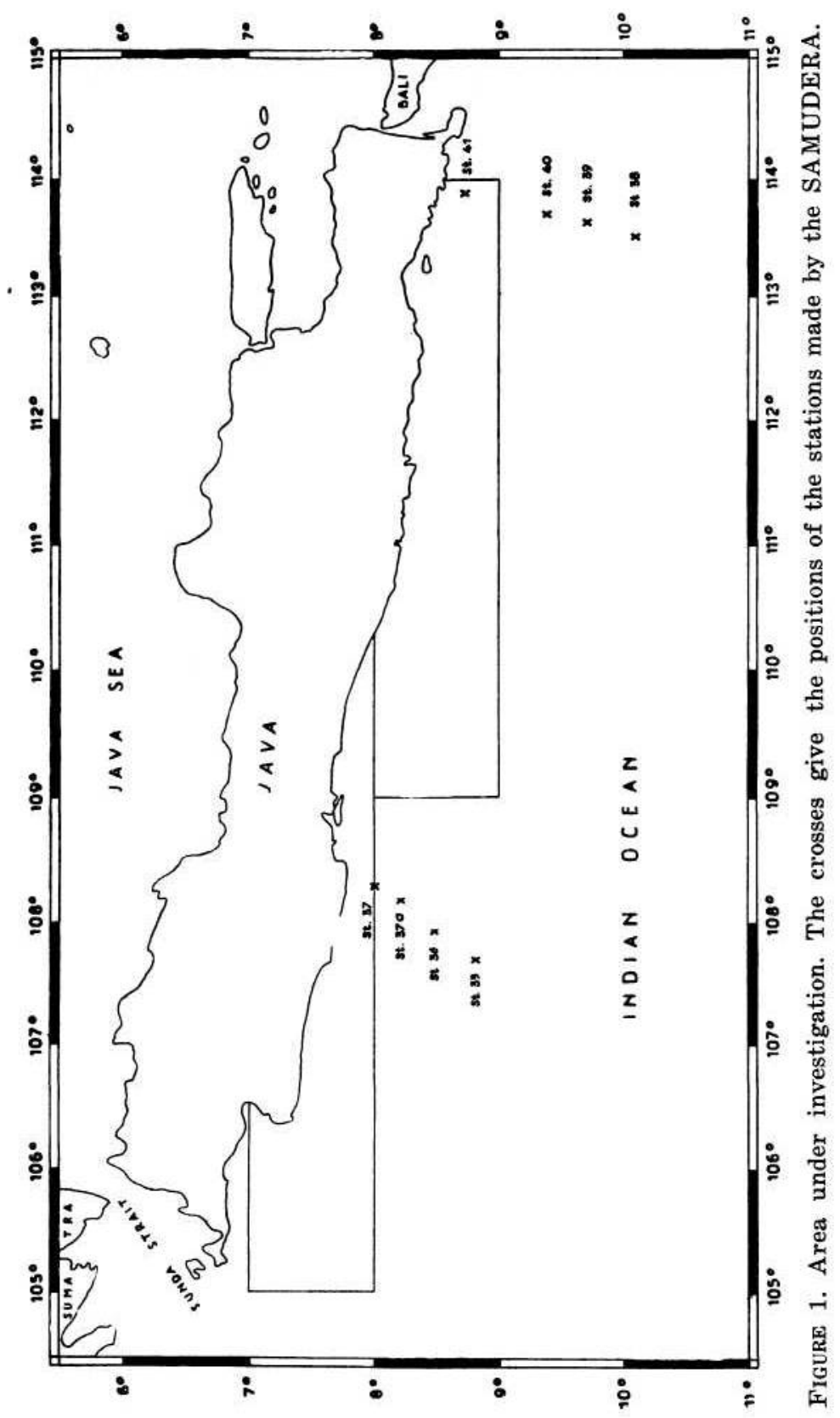




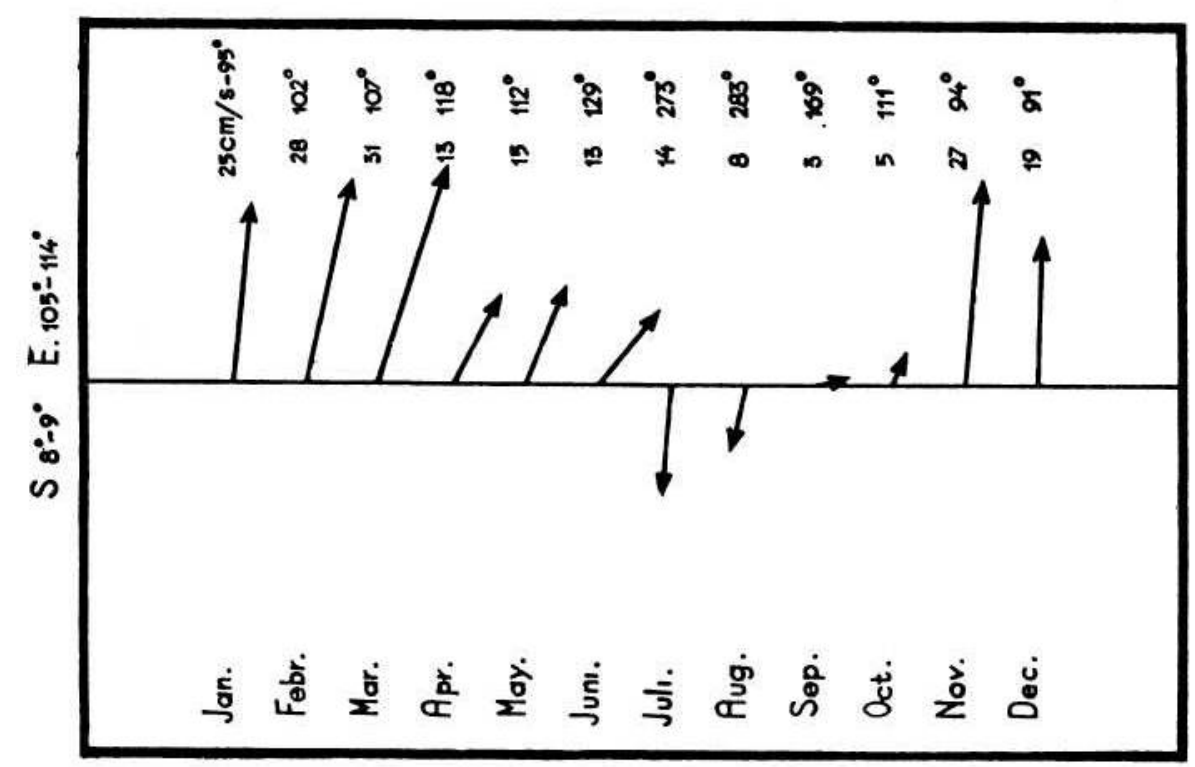


The greatest velocity of $31 \mathrm{~cm} / \mathrm{sec}$ is noted in March, at the end of the full northwest monsoon period, the time of the strongest westerly wind.

In the western part, this current ends in about April and in May water movements to the southwest are observed, which are replaced again in June by movements to the southeast. In the eastern part, the duration of the current is longer and prevails with movements to the southeast until June. This is in contrast to the fact that the southeast monsoon already starts in May. So we have the fact in May and June that the current is running against the monsoon, which leads to the assumption that the Java Coastal Current is not caused predominately by winds.

The annual variations of the surface salinities and their annual means in the western and eastern parts of the coastal waters south of Java are presented in Fig. 3. The graphs are based on the average of the salinity values for each month. The solid lines represent the western and the dotted lines represent the eastern part. The salinity in the western part shows two maxima and two minima. The maxima in September with a salinity of $33.8 \%$ is higher than that in January. The minimum in November-December with a salinity of $33.1 \%$ is higher than that in April. Compared with the salinity in the western part, the salinity in the eastern part shows a much higher value in all months but November. The maximum of $34.4 \%$ o occurs one month later than that in the western part, the minimum of $33.1 \%$ in November coincides with that in the western part. The secondary maximum of $33.8 \%$ in January is to be noted in the same month as in the western part and the secondary minimum of $32.8 \%$ is to be found in April, also coincides with a minimum in the western part. The annual range in salinity in the western and eastern parts are $1.1 \%$ and $1.6 \%$, respectively, while the absolute salinity maximum and minimum are lower in the western part than those in the eastern part by $0.6 \%$ and $0.1 \%$, respectively.

To compare the salinity data of the coastal water south of Java with the data of rainfall in the coastal area of South Java, a graph of rainfall was also inserted in Fig. 3. There is only one maximum and one minimum in rainfall occuring in December and August, respectively, while however there are two maxima and two minima in surface salinity as stated above. The increase in salinity from May to September can be attributed to the decreased rainfall and high evaporation at this period.

During the period of May-June, the eastgoing Java Coastal Current gradually decreases in strength and is finally replaced by the South Equatorial Current in the period of July-October. The latter current 


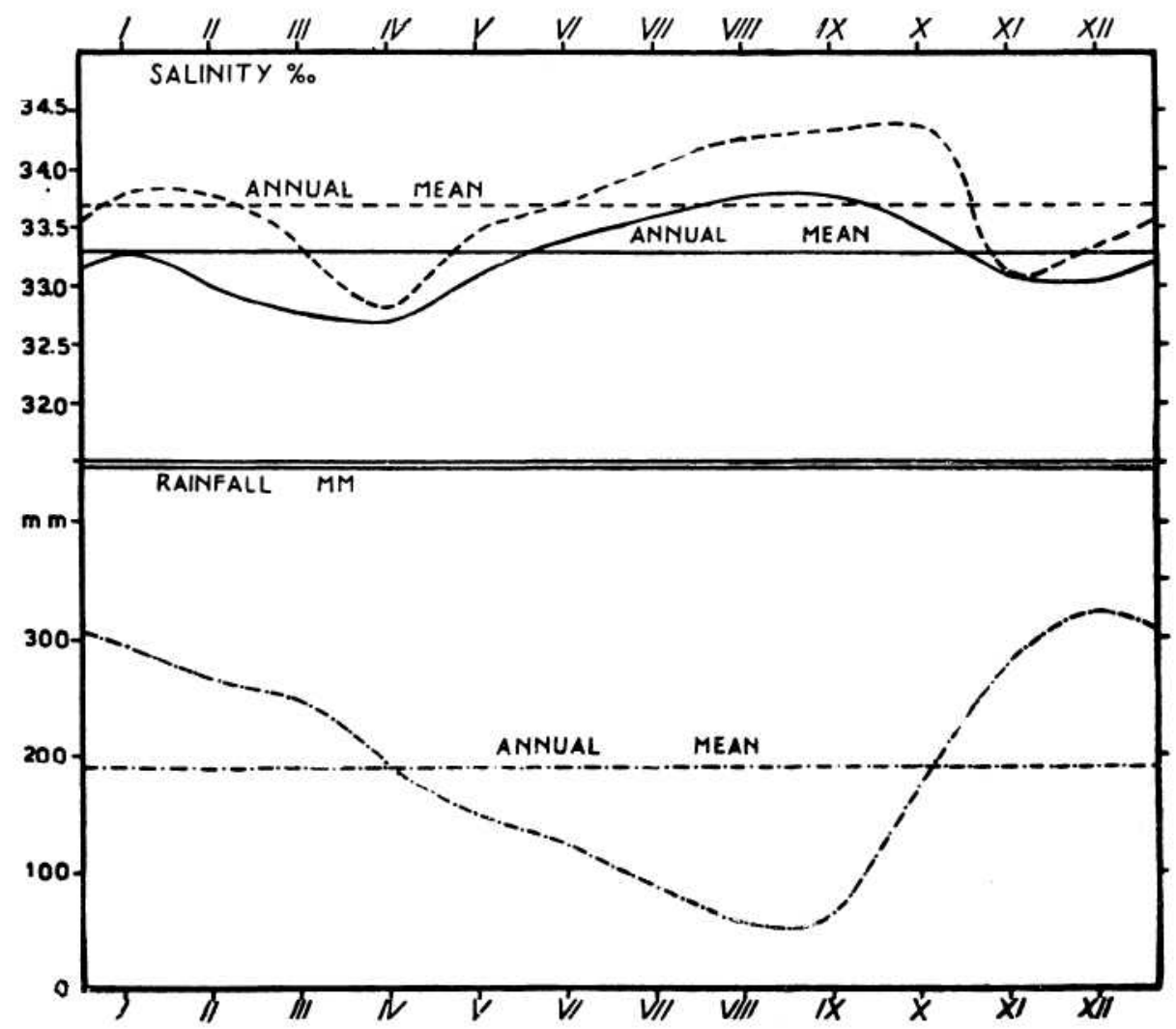

FiguRE 3. Annual variations of the surface salinities and their annual mean in the western part (solid lines), eastern part (dotted lines) of the coastal waters off South Java, and rainfall in the coastal area of South Java. Rainfall data from Verhandelingen No. 37, 1949. 
transports high saline water from the inner part of the Indian Ocean to the south coast of Java, moving less saline water to the west. The invasion of the high saline water is illustrated by a rise in salinity starting in May to a maximum in September-October. The increase in salinities are also partly attributed to the high evaporation in this season. The sudden inset of the Java Coastal Current in November when the South Equatorial Current shifts from the south coast of Java, causes a sudden drop in salinity. The secondary maximum in salinity which occurs in January and February can not be easily explained by movements of water masses. Some favour may be given to the assumption that upwelling processes may cause this maximum. At the boundary of the westgoing South Equatorial Current which has a slight component to the south, and of the Java Coastal Current which has a weak component towards the coast of Java from November to February, a divergence must develop. If this divergence should be strong enough, upwelling of water from lower levels should occur and could increase the salinity in the boundary region. From February to April, the salinity especially in the eastern part, decreases again. This seems to be in fact the spreading of the low saline coastal waters towards the south, which are not longer pressed against the shore by the current.

In February 1957, the SAMUDERA has taken oceanographic observations crossing the coastal current in two sections south of Java at 7 stations. This expedition made measurements down to about $1000 \mathrm{~m}$ and determined temperature, salinity and oxygen with small intervals in depth.

The vertical distribution of temperature, salinity and oxygen in the upper $250 \mathrm{~m}$ are given in Fig. 4 and 5. In the western section (Fig. 4) the homogeneous surface layer extends to a depth of about $100 \mathrm{~m}$, in which the salinity shows small variations. The surface salinities in both stations are $33.73 \%$ and $33.89 \%$, which are higher than the average of surface salinity values in the western parts of the coastal waters of Java as seen in Fig. 3 for the same month. But most of the surface salinity samples collected by the Institute of Marine Research at Djakarta were taken by steamers of several shipping companies, which operate regularly in the region south of Java near the coast. This means that the obtained salinity data represent only a picture of the salinity distribution for the region near the coast. As stated above, the Java Coastal Current as a continuation of the southeast-going current along the west coast of Sumatra shows its strongest development in this month. The considerable fresh water flowing from the rivers of Sumatra and Java 


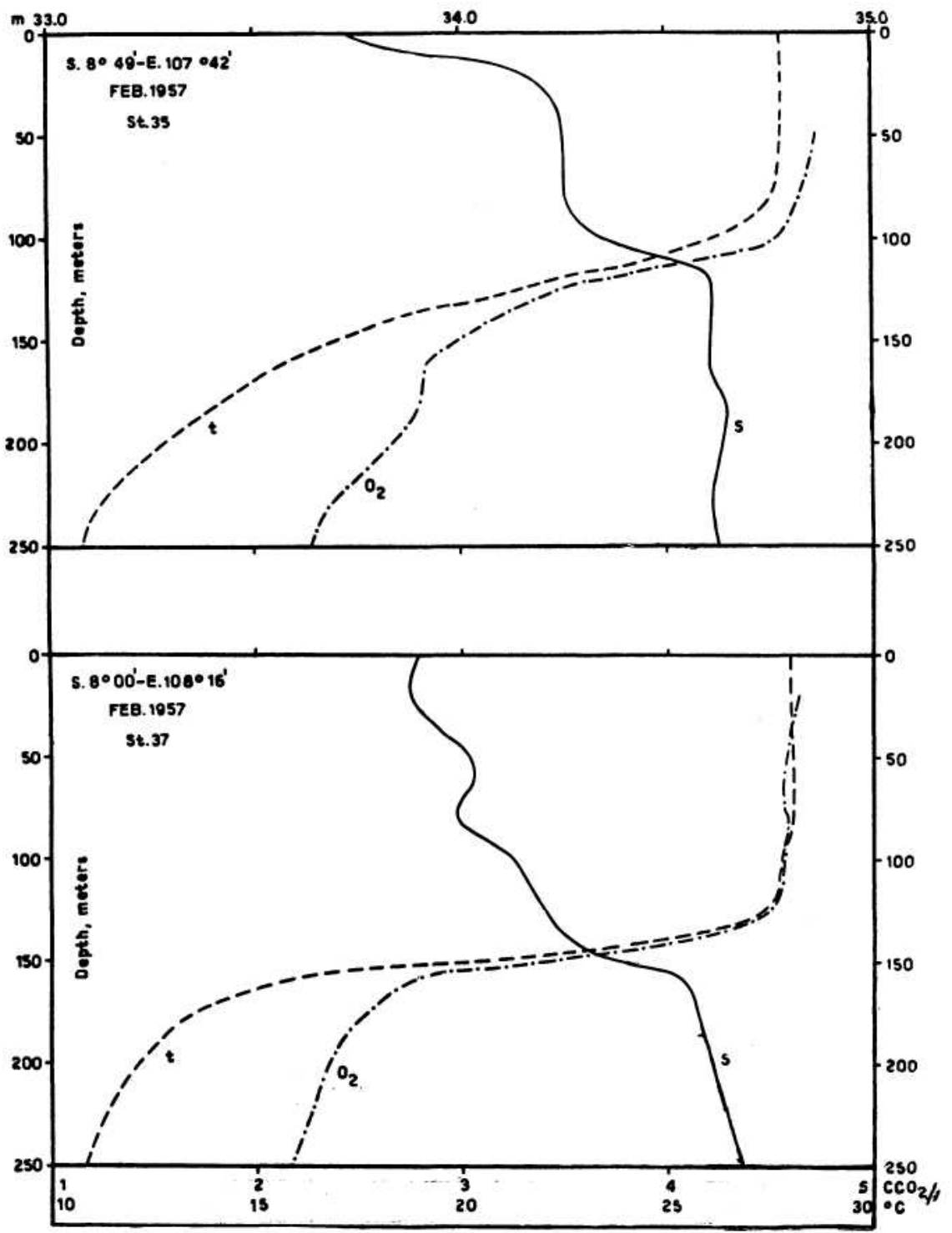

FIGURE 4. Vertical distribution of temperature, salinity and oxygen content at two stations in the western section. 


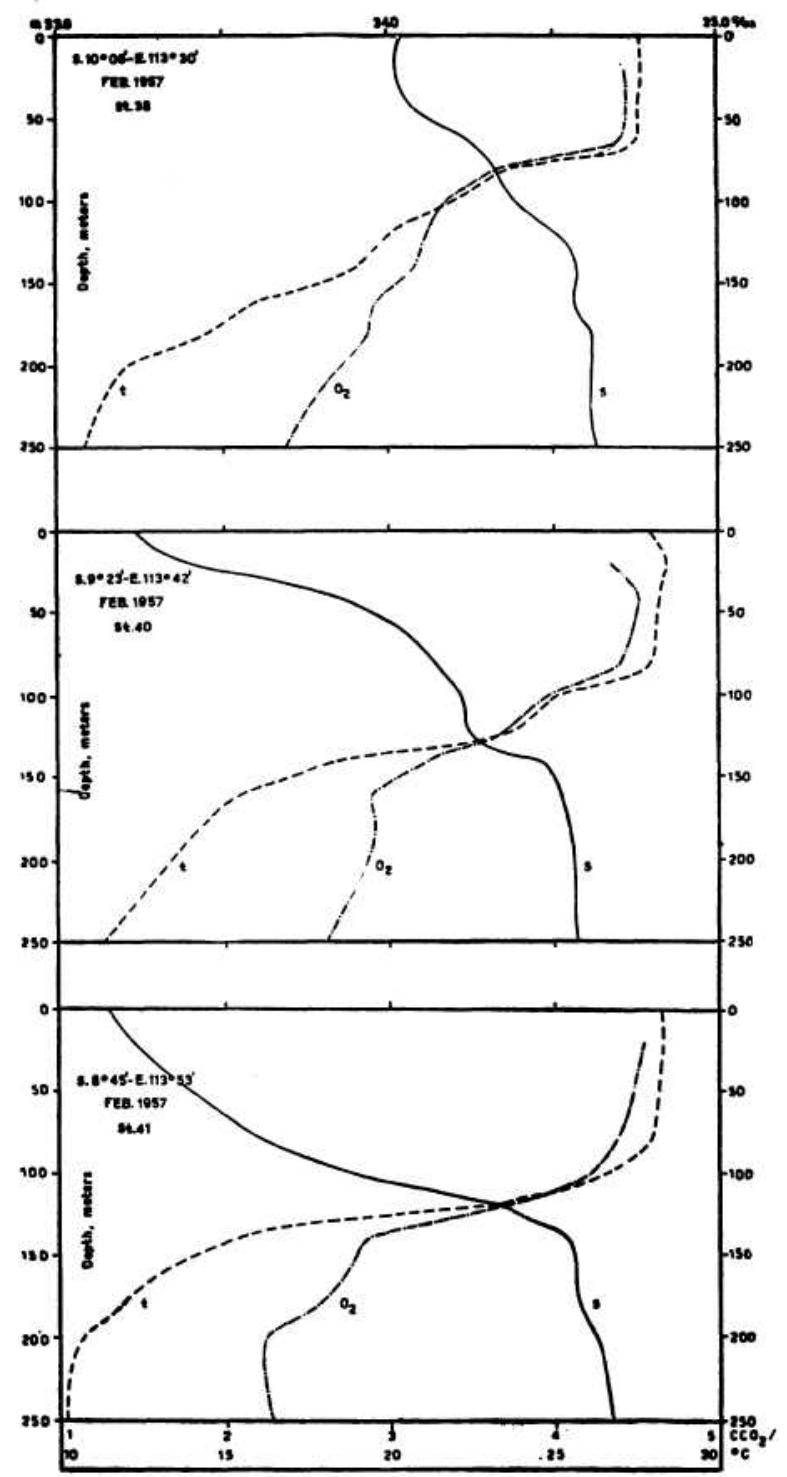

FIGURE 5. Vertical distribution of temperature, salinity and oxygen content at three stations in the eastern section. 
reduces the salinity near the coast. This is the reason, why the average of the surface salinity values of the western part is notably lower than the surface salinities in both stations which are situated further off the coast. The temperature in this homogeneous layer is nearly constant at about 28.0 ${ }^{\circ} \mathrm{C}$, while the oxygen content shows a very slow decrease. Below this layer, the discontinuity layer is found, in which the temperature and oxygen content decrease, the decrease being quite rapid down to $160 \mathrm{~m}$. On the contrary, an increase in salinity to an intermediate maximum is noted.

In the eastern section (Fig. 5), the surface salinity of $34.04 \%$ o at the extreme southern station (st. 38) is significantly higher than those at the two other stations. The homogeneous surface layer reaches down to $60 \mathrm{~m}$. The vertical salinity distribution in this layer shows a small variation, while the temperature of $27.7^{\circ} \mathrm{C}$ and the oxygen content of $4.45 \mathrm{ccm} /$ liter are constant. Below the homogeneous layer a similar pattern is noted as seen at the stations in the western section. At the two other station, the situation is different. The low surface salinities of about $33.20 \%$ gradually increase to their intermediate maxima. The continuous transition of the salinity from the waters of the surface to the intermediate layer is due to the mixing processes of the coastal waters. The homogeneous layer in which the temperature and oxygen content are about constant, extends to a depth of about $90 \mathrm{~m}$. Below it, a similar pattern is maintained as encountered at the other stations.

In studying the differences of the vertical salinity distributions at the three stations, one could see that the extreme southern station lies in the South Equatorial Current, while the other two are situated in the coastal current. It is evident now that the boundary of both currents is at about $10^{\circ} \mathrm{S}$. From this we can draw the conclusion that the Java Coastal Current extends to about 90 nautical miles off the coast.

From the hydrographic observations, dynamical calculations have been made and the currents across both sections have been calculated. Their vertical distributions are illustrated in Fig. 6 and 7. In the western section (Fig. 6), the current extends to a depth of about $150 \mathrm{~m}$, while in the eastern section (Fig. 7), the current extends to a depth of about $250 \mathrm{~m}$. This means that the upper parts of the discontinuity layer are transported with the current.

In the extreme southern station of the eastern section which lies in the South Equatorial Current, the velocity of the current gradually decreases to zero at a depth of $250 \mathrm{~m}$. Approaching the coast, the situation is different. The greatest velocities are noted at a depth of about 


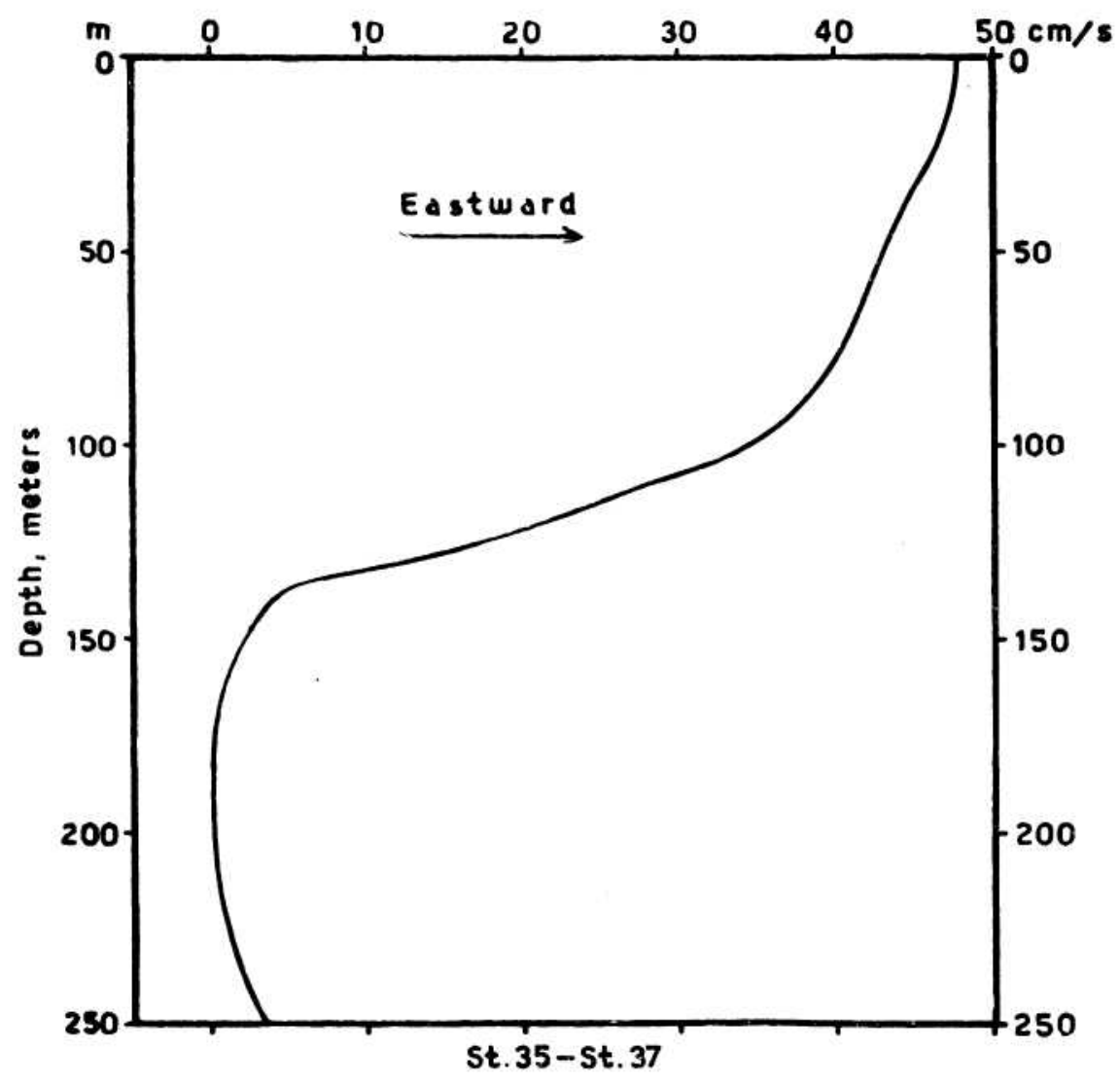

FIGURE 6. Vertical distribution of current velocity between the stations Sa 35 and Sa 37. 


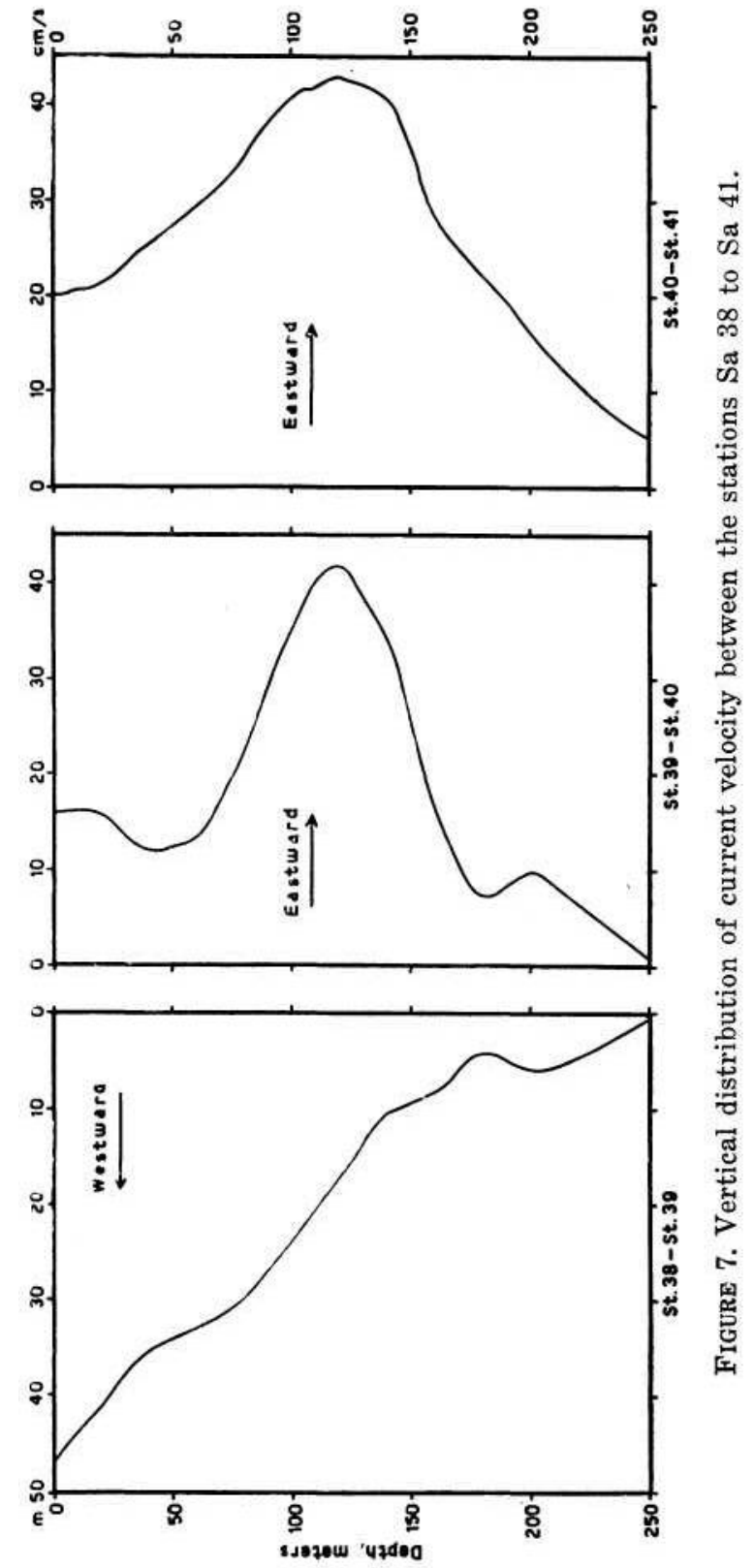



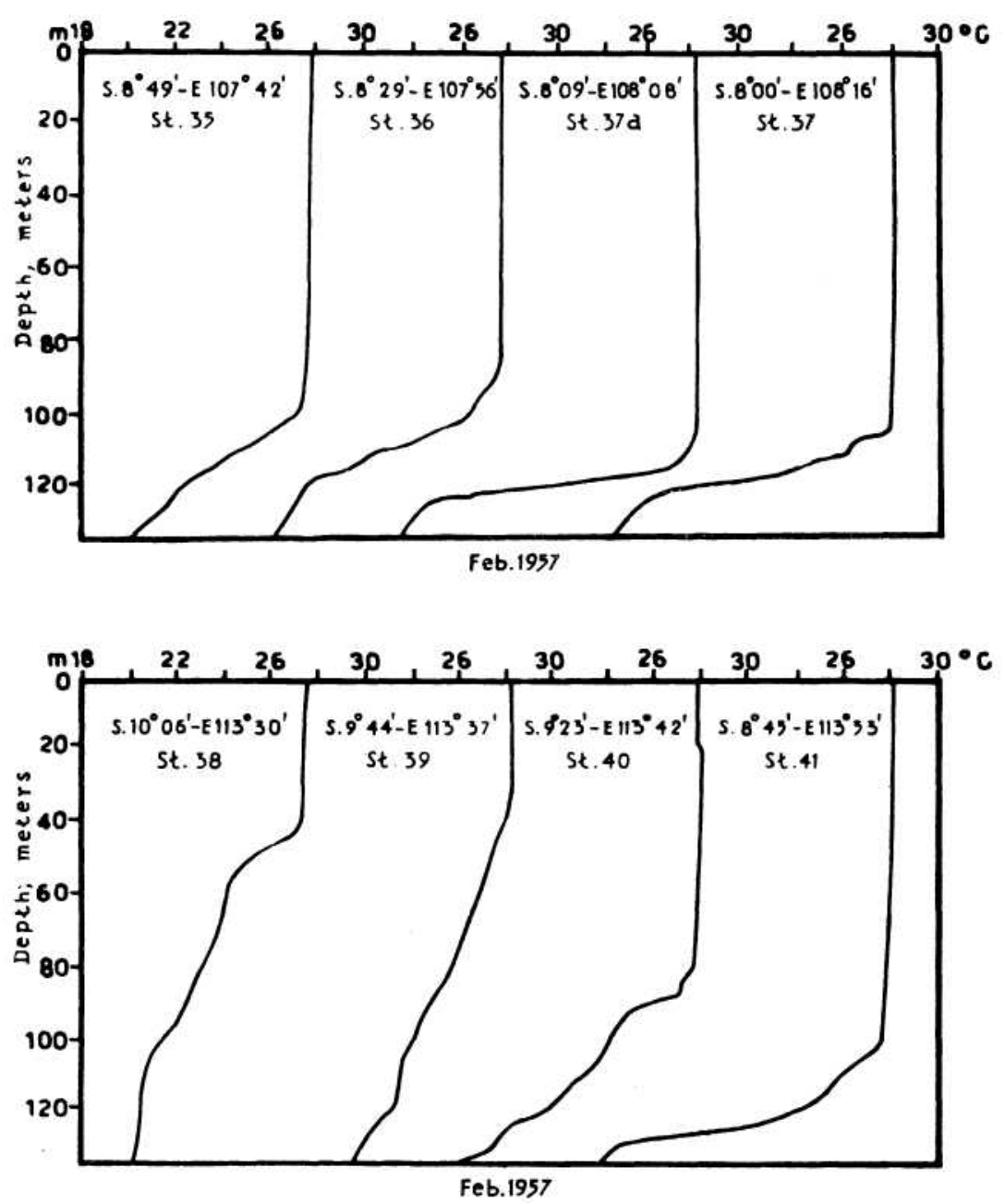

FIGURE 8. Bathythermograph records at the western and eastern sections. 
$120 \mathrm{~m}$. This fact can be attributed to the internal waves and tides, which seem to appear in this region.

The transport of the Java Coastal Current in the western section which takes place above a depth of $150 \mathrm{~m}$ is $4.7 \mathrm{mill} . \mathrm{m}^{3} / \mathrm{sec}$ and the transport in the eastern section in the upper $250 \mathrm{~m}$ is $5.6 \mathrm{mill} . \mathrm{m}^{3} / \mathrm{sec}$.

In February 1957, the research vessel SAMUDERA has also made bathythermograph records in the western and eastern section at the same stations. To illustrate the result of the records Fig. 8 was prepared. Compared with the temperature data obtained from reversing thermometer readings as seen in Fig. 4 and 5, a certain principal pattern is maintained. The homogeneous surface layer extending to a depth of $100 \mathrm{~m}$ is maintained at all stations of the western section, while the thickness of this layer increases from $40 \mathrm{~m}$ at $10^{\circ} \mathrm{S}$. to $100 \mathrm{~m}$ near the coast in the eastern section. The discontinuity layer is found to be essentially sharper at the coast than further off the coast.

Also the bathythermograph records demonstrate that the discontinuity layer in the eastern section lies considerably higher in the southern portion than near the coast of Java. It is assumed that this fact can be attributed to upwelling processes.

\section{SUMMARY}

During the period from November to June, the eastgoing Java Coastal Current develops along the south coast of Java, while from July to October, the westgoing South Equatorial Current reaches the south coast of Java. The eastgoing current reaches maximum velocities of 31 $\mathrm{cm} / \mathrm{sec}$ at the time of full development of the northwest monsoon, while the westgoing current reaches maxima of $14 \mathrm{~cm} / \mathrm{sec}$ and $23 \mathrm{~cm} / \mathrm{sec}$ in the eastern and western part, respectively, during the southeast monsoon.

The annual variation of surface salinity in this area is discussed.

In February 1957, the research vessel "SAMUDERA" obtained oceanographic observations across the current in two section south of Java.

Below the homogeneous layer, which is about 60 to $100 \mathrm{~m}$ deep, the discontinuity layer is found, in which the temperature and the oxygen content decrease and the salinity increases to an intermediate maximum.

The boundery of the Java Coastal Current and the South Equatorial Current is at about $10^{\circ} \mathrm{S}$. in the eastern section, which means that the former current extends to about 90 nautical miles off the coast. 
The transport of the current has been calculated from these observations. The current extends to a depth of about $150 \mathrm{~m}$ and $250 \mathrm{~m}$ in the western and eastern section, respectively, which means that the upper parts of the discontinuity layer are transported with this current.

The bathythermograph records demonstrate that the discontinuity is essentially sharper at the coast of Java than further off the coast. In the western section, the homogeneous layer is nearly constant in depth at 100 $\mathrm{m}$, while in the eastern section it increases from $40 \mathrm{~m}$ at $10^{\circ} \mathrm{S}$. to $100 \mathrm{~m}$ near the shore.

\section{ICHTISAR}

Selama masa dari Nopember sampai Djuni, disepandjang pantai selatan Pulau Djawa berkembang Arus Pantai Pulau Djawa kearah timur, sedang dari Djuli sampai Oktober, Arus Chatulistiwa Selatan jang berarah kebarat sampai dipantai Pulau Djawa. Arus jang ketimur mentjapai ketjepatan maksimum $31 \mathrm{~cm} / \mathrm{sek}$ pada waktu puntjak perkembangannja musim barat laut, sedang arus jang kebarat mentjapai ketjepatan maksimum $14 \mathrm{~cm} / \mathrm{sek}$ dan $23 \mathrm{~cm} / \mathrm{sek}$, masing-masing dibagian timur dan barat selama musim tenggara.

Pergojangan tiap tahun dari kadar garam dipermukaan, didaerah ini telah diuraikan.

Pada bulan Pebruari 1957, kapal penjelidik SAMUDERA mendapat pemeriksaan-pemeriksaan oceanografis menjilang arus didua seksi sebelah selatan Pulau Djawa.

Dibawah lapisan serba sama jang dalamnja l.k. 60 sampai $100 \mathrm{~m}$, terdapat lapisan jang serba tidak berhubungan, dimana suhu dan kadar zat pembakar menurun dan kadar garam menaik sampai maksimum perantaraan.

Diseksi timur, batas Arus Pantai Pulau Djawa dan Arus Chatulistiwa Selatan ada dilintang selatan $10^{\circ}$, jang berarti bahwa arus jang pertama melebar sampai l.k. 90 mil dari pantai.

Dari pemeriksaan-pemeriksaan ini, pemindahan arus telah dihitung. Arus melebar sampai kedalam l.k. $150 \mathrm{~m}$ dan 250 m, masing-masing dibagian barat dan timur, jang berarti bahwa sebagian atas dari lapisan serba tidak berhubungan ikut dipindahkan dengan arus itu.

Tjatatan bathythermograp melukiskan, bahwa lapisan serba tidak berhubungan betul-betul lebih tad jam dipantai Pulau Djawa daripada lebih djauh dari pantai itu. Dibagian barat, lapisan serba sama hampir tetap pada dalam $100 \mathrm{~m}$, sedang dibagian timur menaik dari $40 \mathrm{~m}$ di $10^{\circ}$ lintang selatan sampai $100 \mathrm{~m}$ didekat pantai. 


\section{ACKNOWLEDGMENTS}

It gives me great pleasure to acknowledge my indebtedness to Dr. K. WyRTKI head of the Lembaga Penjelidikan Laut at Djakarta, to Mr. E. H. DAHLGREN fishery adviser to the I.C.A. in Indonesia, and finally to Mr. T. H. Butler, F.A.O. fishery expert and adviser to Sea Fisheries Service in Indonesia for their many helpful criticisms and suggestions in preparing this paper.

\section{REFERENCES}

Berlage, Jr. H. P. 1949. Regenval in Indonesie (Rainfall in Indonesia). Koninklijk Magnetisch en Meteorologisch Observatorium te Batavia. Verhandlingen No. 37, 1949.

HydROGRAPHIC OfFICE U.S. NAVY, 1944. Atlas of surface currents, Indian Ocean 1950.

KoninKLiJK Nederlands Meteorologisch InstituUt No. 124. Sea Areas Round Australia. Oceanographic and Meteorological data. 